\title{
Does Human Capital Mitigate Resource Curse? Evidence in the Short- and Long-Run
}

\author{
Ibrahima Coulibaly $^{1} \&$ Jebaraj Asirvatham ${ }^{2}$ \\ ${ }^{1}$ John A. Logan College, Carterville, Illinois, USA \\ ${ }^{2}$ Department of Agribusiness Economics, Southern Illinois University Carbondale, Illinois, USA \\ Correspondence: Jebaraj Asirvatham, Associate Professor, 1205 Lincoln Dr., Agriculture Building, Agribusiness \\ Economics, Southern Illinois University, Carbondale, IL 62901, USA. Tel: 618-453-1709. E-mail: \\ ajebaraj@gmail.com
}

Received: July 26, 2021

Accepted: September 12, $2021 \quad$ Online Published: September 20, 2021

doi:10.5539/ijef.v13n10p157

URL: https://doi.org/10.5539/ijef.v13n10p157

\begin{abstract}
This paper examines the short-term and long-term relationships among natural resources, human capital, and growth in Mali in an Autoregressive Distributed Lag-Error Correction Model framework. In the presence of natural resources, we find that human capital has a positive impact on growth over time. Results show a long-term, stable and positive relationship between economic growth, natural resources, and human capital. Furthermore, the results do not show evidence of Dutch disease or the presence of any natural resource curse in Mali.
\end{abstract}

Keywords: economic growth, human capital, long-term economic growth, resource economics

JEL: Q32; O1; O4; O5; Q00.

\section{Introduction}

Natural resources endowment has been the main catalyst for economic growth in many developed countries, such as United States, Canada, Australia, and Scandinavian countries. Such positive impacts on economic growth have not been observed in developing countries. On the contrary, developing countries show a "curse of resources", which is a negative relationship between natural resources abundance and economic growth rate (Sachs \& Warner, 1995, 1997, 1999, and 2007). Developing countries endowed with rich natural resources are generally unable to use their wealth to improve their economies, and, in fact, produced smaller economic growth compared to countries without natural resources.

According to many growth economists, an abundance of natural resources endowed promotes economic growth. Stevens (2003) argued that natural resources generate revenues that provide capital, that in turn enhances economic growth and development. Capital growth also reduces foreign exchange fluctuation, which is considered an important barrier to economic growth (Stevens, 2003). Even if such desirable economic growth were not realized in developing countries, one would expect that the presence of natural resources should at least not slow down economic development growth.

Evidence in the literature suggests that an abundance of natural resources in many countries produced mixed results (Gylfason, 2000). Some studies find a positive relationship between natural resources and growth while others report negative association. Analyzing industrial policies of oil-producing countries, Auty (1993) found that the government of rich natural resources countries extracted lower domestic revenues because foreign-owned mining firms repatriated company profits out of the resource-rich countries.

Studies have explored possible mechanisms or transmission channels of natural resources affecting economic growth. Several studies find that natural resources, in the short run, negatively affect growth through human capital (for example, Auty, 1997, 2004, \& 2007). The long-term relationship, however, varies. Findings differ for different countries or regions. There are also not many studies focusing on the long-term relationship between natural resources and human capital. This study analyzes both the long-term and short-term growth impacts.

Alexis's (2004) study attributes resource curse to long-term declining trade, primary export revenue volatility, crowding out of investment, government mismanagement, and corruption as well as low levels of human capital. Many growth economists acknowledge the existence of a resource curse, but the specific mechanisms remain an open question (Gylfason, 2000). 
Mali provides an interesting opportunity to study resource curse because gold, a natural resource, contributes to a significant percentage of Mali's GDP. However, the gold industry has not generated positive ripple effects on other industries. Mali ranks 182 of the 188 countries on the United Nations Human Development index reported by the World Bank. The poverty rate in Mali is 41.9 percent, and agriculture is a primary industry which employs about three-fourth of the population. According to the Earth Resources Observation and Science (EROS), Mali faces drought with frequent soil erosion. The loss of pastureland is a big issue and often leads to ethnic conflicts. Despite its arid climate and vast unoccupied land, Mali has some of the largest gold reserve deposits in the continent (World ATLAS). Mali also has a host of other natural resources, including uranium, diamonds, copper, iron ore, and precious stones. It is also home to a variety of wildlife. With all this natural endowment the country possesses, Mali is still one of the poorest countries in the world.

Gold is an important industry that brings export revenues and a significant portion of the GDP. In 2017, for example, gold industry made $14 \%$ of Mali's GDP, and it constituted $72 \%$ of total exports. Mali is considered resource-rich in gold, according to IMF. IMF (2017) defines a resource-rich country as one in which exports share of natural resources is at least 25\%. Yet on the World Bank indicators, Mali has one of the poorest human capital indicators among Sub-Saharan countries.

This study examines the relationship between natural resources abundance and economic growth with an emphasis on human capital, specifically on Mali. The methods employed allow us to critically examine the role of human capital. Human capital is an important determinant of the skill-level of workers or laborers. Skilled workers with better education are demanded by the manufacturing and service sectors, which compensates workers more than the primary sector (Gylfason, 2000). Higher compensation, among others, makes primary production, such as agriculture, fisheries, and mining, less attractive than the manufacturing and services sectors (Gylfason, 2000). A higher demand for skilled work together with higher compensation gives the right incentive to citizens and the government to invest in human capital, particularly through formal education. Barro and Lee (2000) provide evidence that human capital obtained through education has the greatest impact on economic progress. Previous studies that find a positive relationship between human capital and economic growth point out that increase in human capital accumulation increases worker productivity, thereby inducing economic growth.

This study is organized as follows. Section 2 discusses studies on resource-curse focusing on different transmission channels through which natural resources negatively impact economic growth. In section 3, we briefly discuss studies on the long-term relationship between human capital and growth with some intuitive economic values. Section 4 describes data sources, and Section 5 lays out the methodology. Empirical tests and results are presented in Section 6, followed by conclusions and the implications in Section 7.

\section{The Resource Curse Literature}

Much of the empirical evidence from the resource curse literature suggests an inverse relationship between natural resource-abundance and economic growth in developing countries. Auty (2007) suggests that a favorable natural resource-abundance may be less beneficial to low-income and middle-income countries. Madison (1991) argues that although resources influenced total gross domestic product (GDP) rate of growth in Australia and North America by bringing a large inflow of migrants, its impacts on these countries per capita GDP and rates of growth has been declining over time. According to Auty, the new evidence implies that natural resource rich countries fail to benefit their rich endowment. Furthermore, resource rich countries may perform worse than less rich endowment countries, which is the basis of the resource curse theory (Auty, 2007). In a series of articles on ninety-five natural resource-abundant developing countries during 1970-1989, Sachs and Warner (1995, 1999, and 2000) analyzed the relationship between natural resource-abundance and economic growth. Share of exports to GDP in 1970 was used as an indicator for natural resource-abundance. Setting 2\% growth rate as the threshold for a resource curse, they find a negative correlation between resource-abundance and growth rate.

According to Sachs and Warner (1995, 1999, and 2000), natural resource-abundance fosters rent-seeking, corruption, and government mismanagement. Resource-abundance has encouraged developing countries to engage in protectionist paths through state-led projects of development, perhaps as a strategy to avoid Dutch Disease in other sectors of the economy. Dutch Disease is an economic phenomenon where economic development in one sector, say natural resources, results in the decline of other sectors, such as manufacturing. Countries with much natural endowment generate wealth shocks, and positive wealth shocks creates excess demand for non-traded products, such as houses, which then raises prices of non-traded goods. This works through driving up the derived demand for inputs and labor, which in turn raises input costs and wages. These also have implications for labor productivity in both sectors, i.e., resources-abundant sector and the rest. Specifically, it lowers labor productivity in the resource-endowed sector/industry, since high skilled workers move to 
manufacturing or other industries that offer higher wages for skills. Sachs and Warner $(1995,1999$, and 2000) found that resource intensity was strongly correlated with institutional quality and pro-growth policies. An example of pro-growth policy would be integration into the global economy. The results of their studies also point out that resource-abundance in general impedes the manufacturing sector, as in Dutch Disease.

Sachs and Warner (1995, 1999, and 2000) also find that governments resort to protectionist measures when manufacturing sectors in these countries are negatively affected. Such measures, however, hurt economic growth through a negative impact on trade. To understand how such relationships work, Sachs and Warner studied different transmission channels by including variables, such as share of natural endowment exports, trade openness, investment, rule of law, and investment deflator over GDP deflator in 1970 (i.e., logarithm GDP of 1970). These variables are regressed on average annual growth in real GDP per capita. Their results show that natural resources could have negative impacts on growth (Sachs and Warner, 1997). Indeed, all the other variables found to be important in the other studies were still robust and significant in explaining cross-country growth. The results were robust and consistent across different econometric techniques as well as when estimated using different transmission channels.

Another study investigated the relationships among natural resource-abundance, human capital, and economic growth (Alexis, 2004). They found a negative correlation between human capital (measured as literacy rate) and resource-abundance (arable land used as a proxy). According to Alexis, this strongly supports the presence of a "resource curse."

Transmission channels are essential to understand how resources affect economic growth. These channels include policies and others economic environments. Elissaios and Reyer (2004) examined the direct and indirect impacts of natural resource-abundance on economic growth from 1975 to 1996. They studied several transmission channels through which natural resources abundance might affect economic indices, such as corruption, openness, terms of trade, schooling, and investment. Results showed that natural resources have a negative effect on growth in the absence of other economic indices, but there is a positive and direct impact on growth in the presence of transmission channels.

Resource curse, however, is not a rule among developing countries. A study on Botswana, Chile, Indonesia, and Malaysia finds positive effects of resource endowment on economic growth through different transmission channels (Stevens, 2004). These four countries were selected based on their export revenues from fuel and/or minerals exceeding $30 \%$ of their merchandise exports. Economic indicators among these four countries, as Stevens noted, were higher than the regional benchmarks. For example, Chile's income per capita was higher than the other Latin American countries. Elissaios and Reyer (2004) also point out that there is a strongly positive impact of natural resources abundance on economic growth even after controlling for all other variables in the models. Investment, in their study, showed to be the most important transmission channel that allows resource-abundance to positively impact economic growth.

According to Mehlum, Moene, and Torvik (2006), natural resource rich countries display both growth losers and growth winners. Quality of the institution, according to them, explains the main difference between the success of rich endowment countries and the ones who fail. In the presence of more open and friendly institution, natural resources increase income (Mehlum, Moene, \& Torvik, 2006). Resource-abundance could speed up economic development by increasing the investment rate in resource rich economics relative to the rate in resource-poor endowed countries (Auty, 2014). Abundance of resource helps countries expand their economic capacity to import capital goods to build infrastructure. Boos and Holm-Müller (2013) also show that transmission channels, such as the share of primary exports, amount of trade, consumption and quality of institutions, are found to influence both resource curse.

On a sample of G7 countries from 1980 to 2018, Li et al. (2021) evaluate channels of resource curse. They find that the presence of resource abundance among G7 countries has a positive impact on their country's financial development through the financial markets as the channel and not financial institutions. In the short run, natural resources rent has negative impact on the financial development via financial markets. However, in the long run, there is a positive impact of natural resources rent on the financial development through financial markets among G7 countries.

Uruguay offers a unique case because its economy is naturally resource-abundant, and its economic development is believed to be based on exploitation of its natural wealth. However, a thorough examination over a long period of 144 years of Uruguay history (1870-2014) finds that the influence of natural resources on its economic development is varied and, to some extent, in opposing directions (Sondonato \& Willibald, 2018). Sondonato and Willibald specifically find that the abundance of natural resources induced economic growth during the late third 
of the 19th century and the first few decades of the 20th century. However, this influence faded in the following decades. In other words, there was a positive relationship between natural resources and economic growth in the first stage of development and a progressive reversal of the association in the following decades. They used the Toda-Yamamoto (1995) and Dolado-Lütkepohl (1996) test for Granger-causality, which are extensions of the classic linear non-causality tests within the auto-regressive vectors (VAR) framework. The importance of natural resource in the economy declined as the Uruguay economy became more diversified. A key implication of their study is that there is no sustained continuous long-run causal relationship between the abundance of natural resources and economic performance.

Gerelmaa and Kotani (2016) extend the studies of Sachs and Warner (1995, 1997, and 2001) by using more updated data from 1970-1990 and 1990-2016. They further investigated the relationship between natural resources and economic growth using quantile regression. Their results are consistent with Sachs and Warner studies when a prior period was analyzed, i.e., from 1970-1990. However, the results are contrary when using data during 1990-2016. Furthermore, Dutch disease and natural curse does not appear in the latter years, i.e., 1990-2010. This was attributed to the growth of manufacturing sectors in these countries with abundance of resources. The growth of manufacturing sector was sufficiently large to negate the adverse effect of natural resource on economic growth (Gerelmaa \& Kotani, 2016).

\section{Human Capital and Economic Growth}

Human capital is considered an engine of economic development because it fosters productivity. Human capital has had a greater impact on economic development than nearly every other economic driver (Gylfason, 2001; Barro \& Lee, 2000; Ortega \& Gregorio, 2002). A greater amount of educational attainment indicates a more skilled and productive labor, which contributes to economic growth (Barro \& Lee, 2000). Gylfason (2000) wrote "more and better education is a prerequisite for rapid economic development."

According to Auty (2001), human capital rather than natural resources or physical capital has the greatest influence on economic growth. Although human capital encompasses several aspects, education is the most commonly adopted measure in the literature (for example, Gylfason, 2000). Skilled workers generally prefer working for the manufacturing and services sectors over primary sectors, such as agriculture, fisheries, and mining.

The negative effect of natural resources on economic growth can be reversed by increasing the level of or improving human capital (Ortega \& Gregorio, 2002). They also found that increases in human capital accumulations speed up economic growth in a resource-rich country with high levels of national income. Interestingly, their results also find that natural resources are harmful to economic growth in countries with low human capital accumulation. Thus, negative effects of natural resources on growth could be offset through human capital accumulation.

Some studies, however, find a negative relationship between natural resources and human capital, which results in declining economic growth. For example, using a two-sector endogenous growth model, Asea and Lahiri (1999) provide evidence that natural resources have negative impacts on schooling in the presence of increasing economic incentives for unskilled labor. However, increases in natural resources could raise wages only where there are complementary inputs in the production process among input factors, including labor and natural resources abundance. Thus, natural resources could have negative impacts on human capital accumulation if there is greater complementarity between natural resources and unskilled labor rather than skilled labor (human capital accumulation sector).

Elwasila (2020) studied the relationship between resource rents, human development, and economic growth in Sudan using co-integration and vector error correction modeling (VECM) from period of 1970-2015. Empirical results showed that resource rents and development expenditure positively affected economic growth in the short run. In the long-run, resource rents, school enrollment, life expectancy and financial development have negative impacts on economic growth. Development expenditure has a positive effect on economic growth. That study also found resource rents weaken education and health levels, which have a negative impact on economic growth.

\section{Data}

Complete dataset for this study was obtained from the World Bank database for the period 1980 to 2016. We follow Asea and Lahiri's (2000) study, which borrows from Sachs and Warner's research work, in choosing variables to include in the model. To test for the robustness and consistency of the estimates, we follow Barro and Lee's strategy in model specifications. The outcome variable is the average annual growth rate in real GDP per midyear population. This is defined in the original study done by Sachs and Warner (1985).

We examine education as an engine of long-term growth using ARDL-ECM. Therefore, the dependent variable is 
the difference of the log of real GDP (PPP) per capita, adjusted (constant) between the current year and the previous year. The dependent variable is growth rate per capita 1980-2016 in the log form.

\section{Empirical Approach:}

Autoregressive distributed lag (ARDL) model is used to analyze the relationship between economic variables in a time series set-up. In ARDL, cointegration of nonstationary variables is similar to an error correction process, and the model has a reparameterization in EC form (Engle \& Granger, 1987; Hassler \& Wilters, 2006). The existence of a long run/cointegration relationship can be tested based on the EC model. In a long-run relationship some series are bound together due to equilibrium forces even though the individual time series might move considerably, i.e., or nonstationary.

A bound testing procedure is available to draw conclusive inference that does not require knowing whether the variables are integrated of order zero or one (Pesaran, Shin, \& Smith, 2001). The validity of the bound test relies on normally distributed error terms that are homoscedastic and serially uncorrelated, as well as stability of the coefficients over time. A more parsimonious model for interpretation and forecasting purposes can be estimated after the testing procedure. That is to say, if the bound test does not reject the null hypothesis of no long run relationship, an ARDL model based on the first differences (without an equilibrium correction term) can be estimated (Pesaran, Shin, \& Smith, 2001). Below are the steps to estimate ARDL:

a. Find lags using lag-structure criteria

b. Test stationarity (unit root) using the lags identified in step 1

c. If unit root stationary is integrated of order zero, then we can use a simple regression

d. If unit root stationary at level I(1), we can apply cointegration

e. We can apply ARDL if unit root stationary at level I (0), and the first difference is I(1) and not I(2):

Then test for:

- $\quad$ cointegration and long run form (SR and LR)

- $\quad$ Bound Test (F-Statistic)

Several notations are used in this study. L-01 is lower bound at $1 \%$; L_05 at 5\%; L_1 at 10\%; and L_025 is lower bound at $25 \%$. I (1) is integrated of order $1 ; \mathrm{I}(0)$ is stationarity; and the Pesaran/Shin/Smith ARDL Bound test has an F-stat that is greater than the critical value for I (1) at $1 \%$ level (Table 1 ). The series are cointegrated at $1 \%$ level, so we can use ARDL-ECM which indicates a long-run relationship between the dependent variable and the two exogenous regressors (natural resources and enrollment).

Furthermore, the ARDL model is useful for forecasting and uncovering long-run relationships from short-run dynamics. It is relatively more efficient in the case of small and finite sample sizes. In our study we have a small sample size, which show a combination of I(0), i.e., stationary, and and I(1) integrated at level 1 . Therefore, we used ARDL-EC model.

Table 1. Pesaran /Shin/Smith ARDL bound test (ARDL-ECM bound equation)

\begin{tabular}{ccc}
\hline Integrated of the order & Lower bound $(\mathrm{L})$ & Test statistic \\
\hline I(0) & L - 25 & 4.41 \\
I(1) & L - 25 & 5.52 \\
I(0) & L - 10 & 3.17 \\
I(1) & L - 10 & 4.14 \\
I(0) & L - 5 & 3.79 \\
I(1) & L - 5 & 4.05 \\
I(0) & L - 1 & 5.15 \\
I(1) & L - - & 6.36 \\
\hline
\end{tabular}

Note. Ho: no levels of relationship.

Test criteria: accept if $\mathrm{F}<$ critical value for I ( 0 ) regressors.

Reject if F> critical value for I (1) regressors. Based on the test statistic, we conclude evidence of a long-term relationship between the two time-series.

$\mathrm{T}=-4.859$

Estimating autoregressive distributed lag - Error Correction Model ARDL-ECM 


\subsection{Bounds Co-Integration Test}

If the series are co-integrated, they exhibit a long-run relationship, which implies that:

1) the series are related and can be combined as a linear function

2) even if there are shocks in the short-run, which may impact the movement in the individual series, they converge over time, i.e., in the long-run.

Hence, we ought to estimate both long-run and short-run in models. This suggests that the appropriate estimation techniques are the autoregressive distributed lag (ARDL) and vector-error correction (VEC) models, which are specified as

$$
\begin{aligned}
& \log \left(R G D P_{t}\right)=a_{01}+b_{11} \log \left(R G D P_{t-1}\right)+b_{21} \log S P X_{(t-i)}+b_{31} \log _{\text {Enrols }}(t-i)+\sum_{i=1}^{p} b_{1 j} \Delta y_{(t-i)}+ \\
& \sum_{i=1}^{q 1} a_{2 j} \Delta \log S P X_{(t-i)}+\sum_{i=1}^{q 2} a_{3 j} \operatorname{Llog}_{\text {Enrols }}(t-i)+\varepsilon_{1 t}
\end{aligned}
$$

where, $\log (R G P)=$ is the log of real GDP per capita; $\log S P X=\log$ of natural resources; logEnrols $=\log$ of human resources.

Thee optimal lag orders are indicated by $p$ and $q ; \varepsilon_{l t}$ is a vector of the error terms-unobservable, zero mean, and white noise vector process; (serially uncorrelated or independent).

$P$ is used to denote lags for the dependent variables, and $q$ used for the exogenous variables.

- If there is cointegration, the ECM representation is specified as:

$$
\log \left(R G D P_{t}\right)=\sum_{i=1}^{p} a_{1 j} \Delta y_{(t-i)}+\sum_{i=1}^{q 1} a_{2 j} \Delta \operatorname{logSP} X_{(t-i)}+\sum_{i=1}^{q 2} a_{3 j} \Delta \log _{\operatorname{Enrols}}(t-i)+\lambda E C T_{(t-1)}+\varepsilon_{1 t}
$$

where, $\lambda=\left(1-\sum_{i=1}^{p} \delta_{t}\right)$ is the speed of adjustment parameter with a negative sign.

$\mathrm{ECT}=\log \left(R G D P_{t}\right)-\theta X_{t}$. The error correction term is extracted from residuals from the regression of the long-run equation. The long-run parameter is:

$$
\theta=\sum_{i=1}^{p} \frac{\sum_{i=1}^{q} \beta i}{\alpha}
$$

Coefficients $a_{l i}, a_{2 i}$, and $a_{3 i}$ are the short-run sdynamic coefficient of the model's adjustment long-run equation.

This study hypothesis is that the long-run negative impact of natural resources on the log of RGP per capita is mitigated through human capital.

Bounds test for the Cointegration ARDL (p, q1, q2) model with three variables has the following hypothesis. Coefficient of long run are equal to zero

$$
\begin{aligned}
& \text { Ho: } b_{1 j}=b_{2 j}=b_{3 j}=0, \text { where } j=1,2,3 \\
& \text { Ha: } b_{i j} \neq b_{2 j} \neq b_{3 j} \neq 0
\end{aligned}
$$

\subsection{Robust Tests}

Four robust tests are employed to determine the effect each variable has on the dependent variable. In the following tests, the dependent variable, RGDP (real-GDP) per capita, is in log while the explanatory variables are not in log form. Thus, the interpretation of the variables as a unit increase in the explanatory variable is associated with a certain percentage increase in the dependent variable. Log form of RGDP/capita also makes it a growth rate per capita. Following Asea and Lahiri, the base model here is specified as:

$$
\log \left(R G D P_{t}\right)=I_{t}+\beta_{1} E N R O L S_{t}+\beta_{2} I N V S H_{t}+\varepsilon_{t}
$$

where $\log \left(R G D P_{t}\right)$ is the $\log$ of RGDP.

Other specifications discussed below were run to evaluate the association of growth rate with each variable and the consistency of estimates.

$$
\log \left(R G D P_{t}\right)=I_{t}+\beta_{1} E N R O L S_{t}+\beta_{2} I N V S H_{t}+\beta_{3} S P X+\varepsilon_{t},
$$

The second specification includes natural resources (SPXt) along with all the other control variables listed in the first specification.

$$
\log \left(R G D P_{t}\right)=I_{t}+\beta_{1} E N R O L S_{t}+\beta_{2} I N V S H_{t}+\beta_{3} S P X_{t}+\beta_{4} T O T_{t}+\varepsilon_{t},
$$

The third specification adds term of trade (TOT) following Sachs and Warner.

$$
\log \left(R G D P_{t}\right)=I_{t}+\beta_{1} E N R O L S_{t}+\beta_{2} I_{N V S H_{t}}+\beta_{3} S P X_{t}+\beta_{4} T O T_{t}+\beta_{5} \text { SOPEN }_{t}+\varepsilon_{t},
$$

In the final (fourth) specification, we include trade openness $\left(\mathrm{SOPEN}_{\mathrm{t}}\right)$. The data spans a 36-year period. 
Dickey-Fuller (DF) test was employed to test for unit root. DF test suggests that the data are stationary. Error terms, in these models, are assumed not to be correlated over time since the dependent variable, i.e., real growth rate, is the log differential, and log of initial income is the explanatory variable.

\section{Empirical Tests}

A time series often possesses serial dependence because of its very nature that it is indexed in time. To establish reliable estimates in the models, we conduct test diagnostics on serial autocorrelation, heteroscedasticity and normality followed by testing presence of short- and long-run relationships. Stability diagnostics are presented further in this section.

\subsection{Test Diagnostics}

In table I, the standard error is smaller with smaller coefficient, and the F-value is smaller suggesting serial correlation (Green, 2008a). In Table 2, Durbin-Watson values are less than 2, meaning there is serial correlation, which is also confirmed by the Breutch-Godfrey LM test for autocorrelation. Graphical analysis using ACBartless Correlogram at 5\% also shows no serial correlation. The same regression is rerun after reweighting each variable, namely $\log (\mathrm{RGDPt}), \log (E N R O L S)$, and $\log (\mathrm{SPX})$ (Table 2). Breusch-Godfrey test confirms that there is no serial correlation. After taking the first difference of the AC correlogram, the model ARDL-ECM seems to show no serial correlation as indicated by the fact that all residuals seem to fit within the standard error bands as shown in the figure showing cumulative sum (CUSUM) of recursive residuals estimates (Figure 1). We also test for heteroscedasticity. White's test shows there is heteroskedasticity (Table 4). However, after reweighting the variables, the model shows no heteroscedasticity at 5\% significance level.

Three tests were conducted to evaluate the model residuals and provide diagnostics for model adequacy. Graphing the residuals on the $\mathrm{x}$-axis with density of the data points on the $\mathrm{y}$-axis reveals a bell-shaped distribution of the residuals (Figure 1A, Appendix). This bell-shaped histogram plot confirms normality.

Table 2. OLS estimates on the log of Real GDP. $\mathrm{N}=26$

\begin{tabular}{ccc}
\hline Variables & Coeff. & SE \\
\hline LogEnrols_w & -0.346 & 0.489 \\
logSPX_w & 0.039 & 0.96 \\
Cons. & 0.153 & 0.09 \\
\hline
\end{tabular}

Note. $\mathrm{F}(2,23)=0.91($ Prob> F = 0.4181). R-squared = 0.073 (Adj-R-squared = -0.0076). logSPX_w denotes logarithm of natural resources; logEnrols_W denote logarithm of enrollment.

Table 3. Breusch-Godfrey LM test for autocorrelation tests

\begin{tabular}{cccc}
\hline DW d-stat $(\mathrm{k}, \mathrm{N})$ & Chi-sq & df & Prob. \\
\hline $1.38(6,35)$ & 0.172 & 1 & 0.678 \\
$1.38(4,21)$ & 3.150 & 1 & 0.075 \\
\hline
\end{tabular}

Note. Ho: no serial correlation. Lags $(\mathrm{p})=1 \mathrm{~N}$ is the number of observations and $\mathrm{k}$ is the number of regressors.

Table 4. White's test for heteroscedasticity.

\begin{tabular}{ccc}
\hline Test & Chi-square (9) & Prob. \\
\hline White's test & 35.01 & 0.0001 \\
White's test after reweighting & 15.80 & 0.07 \\
\hline
\end{tabular}

Note. Ho: Homoskedasticity. Ha: Unrestricted heteroskedasticity.

\subsection{Short- and Long-Run Relationships}

To examine whether there is a long-run relationship between natural resources and log of RGP per capita and human capital, we use the ARDL-ECM model. Table 5 shows that the maximum lag values are $\left(\begin{array}{lll}1 & 0 & 0\end{array}\right)$ at $5 \%$ level. The Pesaran/Shin/Smith ARDL Bound test has an F-stat that is greater than the critical value for I(1) at $1 \%$ level (Table 6). The series are cointegrated at $1 \%$ level which indicates a long-run relationship between the dependent variable and the two exogenous regressors, i.e., natural resources and enrollment. Cointegration also implies no presence of unit root in this model, based on the ADRL -ECM criteria established that the series are cointegrated. Therefore, this study estimates the long-run relationship between variables.

Table 6 shows estimates from ARDL-ECM estimation, which shows that the adjustment term is negative and 
statistically significant, thereby suggesting that the previous year's errors (or deviation from the long-run equation) are corrected within the current year at a convergence speed of -0.608 on average at the $1 \%$ level, ceteris-paribus. In the long-run, the variable natural resources are positive but statistically insignificant. The human capital variable is positive and has a statistically significant impact on the log of real GDP per capital at $1 \%$ level. A unit increase in human capital, as defined here, will result in a 0.013 increase in the log of RGDP per capita (log of RGDP Per capita). This might imply that, in the long run, the education sector may have a bigger impact on Mali's real GDP per capita as long as the natural resources are used for education.

Table 5. ARDL-ECM Bound equation by Lags

\begin{tabular}{cccccccc}
\hline Lag & LL & LR & p-value & PPE & AIC & HQIC & SBIC \\
\hline $\mathbf{0}$ & -175.54 & & & 10.046 & 10.82 & 10.86 \\
$\mathbf{1}$ & -40.71 & $269.67^{*}$ & 0.0001 & $0.004^{*}$ & $3.19^{*}$ & $3.37^{*}$ \\
$\mathbf{2}$ & 34.98 & 11.45 & 0.246 & 0.006 & 3.39 & 3.71 \\
$\mathbf{3}$ & -27.9 & 14.16 & 0.117 & 0.007 & 3.50 & 3.34 \\
$\mathbf{4}$ & -23.33 & 9.13 & 0.425 & 0.01 & 3.77 & 4.32 & 5.54 \\
\hline
\end{tabular}

Note. degrees of freedom in all cases $=9$.

Column headers are abbreviated as follows: SBIC for Schwarz Bayes Information Criterion; HQC for Hannan-Quinn Criterion; AIC for Akaike Information Criterion, LR is the general-to-specific sequential Likelihood Ratio test, and LL stands for log Likelihood.

Max lag (1) statistically significant at $1 \%$.

Table 6. ARDL_ECM bound test on long-run and short-run adjustment (ECM equation). N=36

\begin{tabular}{ccc}
\hline D. Log RGDP/capita & Coeff. & SE \\
\hline Adj. Log RGDP/capita & $-0.608^{*}$ & 0.125 \\
LR. SPX & 0.002 & 0.007 \\
Enrollment & $0.013^{*}$ & 0.001 \\
Constant & $1.67^{*}$ & 0.34 \\
\hline
\end{tabular}

Note. R-Squared $=0.43$. Adj R-squared $=0.38$

Root MSE = 0.0794. Adj. note adjustment of the Log RGDP per capita Long-Run (LR); Short-run (SR).

\subsection{Stability Diagnostics}

According to the CUSUM Recursive estimates (OLS only) test, as shown in Figure 1, a model is dynamically stable if the cumulative sum (blue trend line) is between the two critical lines (red lines). The model is dynamically stable because the blue line lies between the two red lines.

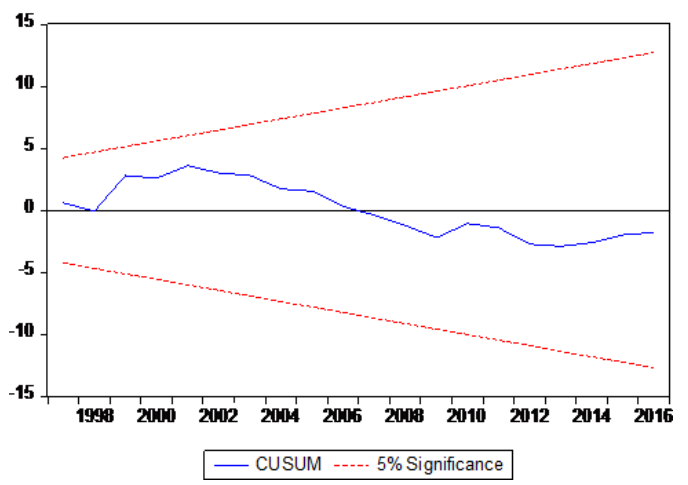

Figure 1. CUSUM recursive estimates

\section{Empirical Results}

Table 7 displays estimates of variables under different regression specifications. Human capital stock is included as the main transmission channel that affects growth in the presence of natural resources. Natural resource curse theory posits that human capital would lose its significance to explain growth rates in the model. The results of this study, however, provide no evidence of resource curse. ENROLS, representing human capital in this study, even 
though statistically significant, is small in magnitude. In specification (1), the investment variable (INVSH) and human capital variable (ENROLS) have positive signs. The ENROLS variable is significant but INVSH is not.

In the second specification, the natural resources (SPX) variable is included and ENROLS is statistically significant, while the coefficient of natural resources (SPX) has a positive marginal effect but with a slightly higher p-value. INVSH, however, is not significant even in the presence natural resources. Term of trade (TOT) is added on to the model in the third specification, (3) In this model, ENROLS is significant and INVSH is insignificant, as in the second specification, (2) However, SPX showed a lower p-value. It could be that a favorable trade agreement between Mali and the rest of the world makes the natural resources exports more valuable and, thereby, generates more revenue for these natural resources exporting countries. The investment variable is not significant. If the investment parameter to impact the continent growth positively, a poor country like Mali may have to rely more on foreign investment to boost the investment variable.

All of these results do not seem to suggest the presence of either Dutch Disease or resources curse in Mali. If Mali could increase the foreign inflow investment directed towards manufacturing and services along the human capital to growth its economy. In the regression specification (4), the ENROLS variable is positive and significant in explaining growth, whereas the INVSH and SPX variables are positive but not significant in the presence of trade openness variable (SOPEN). Taken together, these robust test results do not show evidence of Dutch Disease or even the presence of a natural resource curse in Mali.

Table 7. Impacts of human capital and natural resources on Log real GDP per capita (log GR8016) Mali

\begin{tabular}{lcccc}
\hline & \multicolumn{3}{c}{ Models } \\
\cline { 2 - 5 } Variables & $(1)$ & $(2)$ & $(3)$ & $(4)$ \\
\hline Constant & $2.75^{* *}$ & $2.68^{* *}$ & $2.95^{* *}$ & $(0.149)$ \\
ENROLS & $(0.15)$ & $(0.15)$ & $0.010^{* *}$ & $(0.23)$ \\
SE & $0.0101^{* *}$ & $0.008^{* *}$ & $(0.001)$ & $0.007^{* *}$ \\
INVSH & $(0.001)$ & $(0.002)$ & -0.004 & $(0.001)$ \\
SE & 0.006 & 0.0015 & $(0.007)$ & 0.005 \\
SXP & $(0.008)$ & $(0.008)$ & $0.022^{* *}$ & $(0.007)$ \\
SE & & 0.015 & $(0.007)$ & 0.009 \\
TOT & & $(0.008)$ & $-0.002^{* *}$ & $-0.001^{* *}$ \\
SE & & & $(0.0006)$ & $(0.005)$ \\
SOPEN & & & $0.010^{* *}$ \\
SE & & & $(0.003)$ \\
R-squared (adjusted) & & & 0.72 \\
SE & 0.46 & 0.50 & 0.64 & 0.103 \\
F-TEST & 0.14 & 0.1482 & 0.119 & $120.44^{* *}$ \\
OBSERVATION & $16.69^{* *}$ & $13.10^{* *}$ & $17.15^{* *}$ & 37 \\
\hline
\end{tabular}

Note. $*, * *, \& * * *$ denote significance at $1 \%, 5 \%, \& 10 \%$, respectively.

\section{Discussion and Conclusions}

Natural resource curse is commonly known to exist in developing countries. Some studies, however, do not report similar findings. The first objective of this study was to examine resource curse in a resource-rich developing country, Mali. The second objective was to examine the specific role of human resources.

Mali's economy and population are smaller compared to many Sub-Saharan Africa countries. Mali is also very poor and prone to sporadic conflict. Given this context, the overall results point to a positive direction when it comes to short- and long-term association between natural resources, human capital, and economic growth using ARDL-ECM model. It is important to note that this study did not include variables of conflict, government instability, and drought in this model. Future study could extend the model by including these variables to see if natural resources still have a positive long-term relationship with economic growth variables. This study underscores the need to examine each country that is resource-rich and understand the context before recommending policy solutions. This research also highlights the need to expand the model by including variables and extend the time period of analysis before making a conclusive forecasting and policy recommendation.

The main results of this study are that Mali shows no evidence of resource curse or Dutch Disease. In the short run, free trade boosts poverty reduction. In the long run, variable enrollment and natural resources have statistically 
significant impacts on the real GDP per capita. Throughout the analysis, human capital comes out to be the main beneficiary of trade liberalization.

The results of this study confirm a long-term, stable and positive association between economic growth, natural resources and human capital. This finding affirms the need for Mali to strengthen its trade relations with other nations and use its natural resources endowments as investment to promote human capital accumulation. Human capital, as shown in the literature, exerts the greatest impact on economic growth (Barro 2000, for example).

Mali cannot reap the benefits of free trade yet due to its lack of diversification in the products exported. However, the main consistent variable that seems to have sustainable long-term impact on the poverty reduction is human capital. To minimize negative externality and promote investment geared to knowledge, Mali's government would perhaps be better off utilizing its mineral revenue to promote education, along with creating knowledge-based industries, which will eventually induce growth.

\section{Aknowledgements}

The authors acknowledge the editorial assistance of Barbara James. Brianna Thornton helped in formatting the manuscript and provided other assistance. Comments and suggestions from the editor and reviewers has improved the manuscript, and we're thankful.

\section{References}

Alexis, M. (2004). Human Capital as a Transmission Mechanism of the Resource Curse. The Park Place Economist, 12. Retrieved from http://digitalcommons.iwu.edu/parkplace/vol12/iss1/17)

Asea, P., \& Amartya, L. (1999). The Precious Bane. Journal of Economics Dynamics and Control, 23, 823-849. https://doi.org/10.1016/S0165-1889(98)00045-1

Auty, R. (1993). Sustaining Development in Mineral Economies: The Resource Curse Thesis. Routledge, London. https://doi.org/10.4324/9780203422595

Auty, R. (2001). Resource abundance and economic development. Oxford University Press. https://doi.org/10.1093/0199275785.001.0001

Auty, R. (2007). Natural Resources, Capital Accumulation and The Resource Curse. Ecological Economics, 61(4). https://doi.org/10.1016/j.ecolecon.2006.09.006

Auty, R. (2014). Handbook Sustainable Development. Chapter. https://doi.org/10.4337/9781782544708.00028

Barro, R. J., \& Jong-Wha, L. (2000). International Data on Educational Attainment: Updates and Implications. Oxford Journals. https://doi.org/10.1093/oep/53.3.541

Boos, A., \& Müller, K. M. (2013). The Relationship Between the Resource Curse and Genuine Savings: Empirical Evidence for Food and Resource Economic. Journal of Sustainable Development. University of Bonn, Germany. https://doi.org/10.5539/jsd.v6n6p59

Claire, M. (2011). Natural resources and development: The gold sector in Mali. Resources Policy, 36, 123-131. https://doi.org/10.1016/j.resourpol.2010.10.001

Claudio, B. O., and Jose, De G. (2002). The Relative Richness of the Poor: Natural Resources, Human Capital and Economic Growth. World Bank policy research Working Paper series, 34-84.

Earth Resources Observation and Science (EROS). (n. d). Countries Profile. Retrieved from https://eros.usgs.gov/westafrica/country/republic-mali

Engle, R. F., \& Granger, C. W. J. (1987). Co-integration and error correction: representation, estimation, and testing. Econometrica, 55(2), 251-276. https://doi.org/10.2307/1913236

Greene, W. (2008a). Econometric Analysis (6th ed.). Prentice Hall, Upper Saddle River, NJ.

Hassler, U., \& Wolters, J. (2006). Autoregressive distributed lag models and cointegration. Allgemeines Statistisches Archive, 90(1), 59-74. https://doi.org/10.1007/s10182-006-0221-5

IMF. (2000, 2006, 2008, 2012, 2014, 2017). Country reports.

Lanne, R. (2000). Near unit roots, cointegration, and the term structure of interest rates. The Journal of Applied Econometrics, 15(5). https://doi.org/10.1002/1099-1255(200009/10)15

Lkhagva, G., \& Kodji, K. (2016). Further investigation of natural resources and economic growth: Do natural resources depress economic growth? Resources Policy, 50, 312-321. https://doi.org/10.1016/j.resourpol.2016.10.004 
Maddison, A. (1991). Dynamic Forces in Capitalist Development. Oxford: Oxford University Press. https://doi.org/10.2307/2234406

Mehlum, H., Moene, K., \& Torvik, R. (2006). Cursed by Resource or Institutions. The World Economy, 29(8). https://doi.org/10.1111/j.1467-9701.2006.00808.x

Mohamed, E. (2020). Resource Rents, Human Development and Economic Growth in Sudan. Economies, 8. https://doi.org/10.3390/economies8040099

Papyrakis, E., \& Reyer, G. (2004). The resource curse hypothesis and its transmission channels. Journal of Comparative Economics, 32, 181-193. https://doi.org/10.1016/j.jce.2003.11.002

Pesaran, M. H., Shin, Y., \& Smith, R. (2001). Bounds testing approaches to the analysis of level relationships. Journal of Applied Econometrics, 16(3), 289-326. https://doi.org/10.1002/jae.616

Sachs, J. D., \& Andrew, M. W. (1997). Source of low growth in African Economics. Journal of African Economies, 6, 335-376. https://doi.org/10.1093/oxfordjournals.jae.a020932

Sachs, J. D., \& Andrew, M. W. (2001). Natural Resources and Economic Development: The curse of natural resources. European Economic Review, 45, 827-838. https://doi.org/10.1016/S0014-2921(01)00125-8

Sachs, J. D., \& Warner, A. M. (1995). Economic Reform and the Process of Global Integration. Brookings Papers on Economic Activity, 1, 1-118. https://doi.org/10.2307/2534573

Sachs, J. D., \& Warner, A. M. (1999). The big push, natural resource booms and growth. Journal of Development Economics, 59, 43-76. https://doi.org/10.1016/S0304-3878(99)00005-X

Sandonato, S., \& Willebald, H. (2018). Natural Capital, Domestic Product and Proximate Causes of Economic Growth in the Long Run, 1870-2014. Sustainability, 10, 715. https://doi.org/10.3390/su10030715

Sawe, B. E. (2020). What Are The Major Natural Resources Of Mali? World Atlas. Retrieved from https://www.worldatlas.com/articles/what-are-the-major-natural-resources-of-mali.html

Songyun, et al. (2021). Understanding the dynamics of resource curse in G7 countries: The role of natural resource rents and the three facets of financial development. Resources Policy, 73. https://doi.org/10.1016/j.mulfin.2020.100641

Stevens, P. (2003). Resource Impact: A Curse or a Blessing. Centre for Energy, Petroleum and Mineral Law and Policy. University of Dundee, Dundee UK.

Thorvaldur, G. (2001). Natural resources, education, and economic development. European Economic Review. https://doi.org/10.1016/S0014-2921(01)00127-1

UNCTAD. (2009). Handbook of Statistics. Geneva.

USAID. (2019). Country Profile. Retrieved from https://www.usaid.gov/mali/fact-sheets/mali-country-profile

World Bank. (2017). Growth support Project. Retrieved from http://www.worldbank.org/ida

World Bank. (2018). Dataset for a panel of 1 country; Database indicators. Retrieved from http://www.worldbank.org/ida

\section{Appendix}

Variables descriptions: Variables from Sachs and Warner (1997) were used for estimation tables to estimate our variables

$\mathbf{I}_{\mathbf{t}}$ : Natural $\log$ of real GDP divided by the economically active population in 1980 . The Real GDP data correspond to the series

$\log \left(\mathbf{R} G D P_{\mathbf{t}}\right): \log$ Average annual growth in real GDP divided by the economically active population between the years 1980 and 2016.

SXP: Share of exports of natural resources products in GDP. According to the criteria in Sachs and Warner [1997].

SOPEN: The fraction of years during the period 1980-2016 in which the country is rated as an open economy according to the criteria in Sachs and Warner (1995).

INVSH: Real gross domestic investment (public plus private) to real GDP, averaged over the period 1980-2016.

TOT: Term of trade. Average annual growth in the external terms of trade between 1980 and 2016. The external 
terms of trade are the ratio of an export price index to an import price index.

ENROLS: Used the secondary enrollment rate as a proxy for human capital.

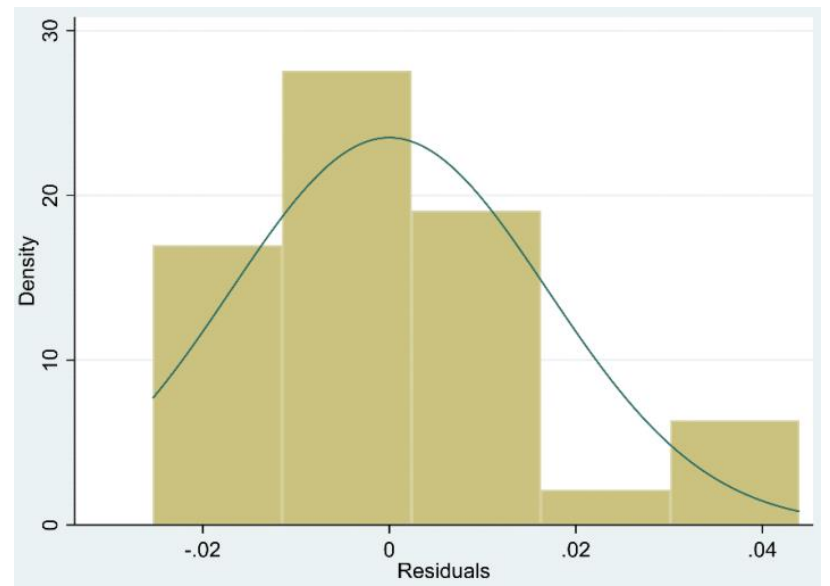

Figure 1A. Normality test

\section{Copyrights}

Copyright for this article is retained by the author(s), with first publication rights granted to the journal.

This is an open-access article distributed under the terms and conditions of the Creative Commons Attribution license (http://creativecommons.org/licenses/by/4.0/). 